\title{
An Evaluation of the Measurement of Perceived Classroom Assessment Environment
}

\section{Hussain Alkharusi}

Sultan Qaboos University, Oman, hussein5@squ.edu.om

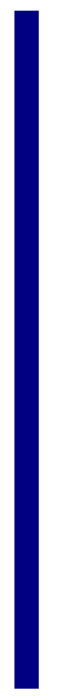

A classroom assessment environment is a classroom context experienced by students as the teacher determines assessment purposes, develops assessment tasks, defines assessment criteria and standards, provides feedback, and monitors outcomes (Brookhart, 1997). It is usually a group experience varying from class to class dependent upon the teacher's assessment practices (Brookhart, 2004). As such, the measurement of class-level perception of the assessment environment should deserve recognition and investigation. This study aimed at evaluating the measurement of the perceived classroom assessment environment by comparing the psychometric properties of the scale at the student level and class level. Using a multi-stage random sampling process, data were collected from 4088 students nested within 236 classes of the second cycle of the basic education in the Sultanate of Oman. Students responded to the 18-items of Alkharusi's (2011) Perceived Classroom Assessment Environment Scale. Results of the principal axis factoring yielded two factors, learning-oriented and performance-oriented assessment environment, at both levels. However, the two factors explained about $38 \%$ of the variance at the class level compared to about $20 \%$ of the variance at the student level. Reliability coefficients in terms of Cronbach alpha ranged between .79 and .83 at the class level compared to .65 and .67 at the student level.

Key Words: validity, reliability, evaluation, measurement, classroom assessment, student perceptions, assessment environment

\section{INTRODUCTION}

Teachers' assessment practices have been the focus of much attention for over the past years. However, significant interest in classroom assessment environment is a recent phenomenon. The classroom assessment environment represents an important component of the classroom climate (Brookhart \& DeVoge, 1999). It involves exposing students to a variety of assessment practices created largely by the teacher (Brookhart, Walsh, \& Zientarski, 2004). An issue that has received increased attention by educational assessment researchers is what do students think about the assessment practices that are used to evaluate their academic achievement. For example, Dorman and Knightley (2006) designed an inventory to measure students' perceptions of the assessment tasks in terms of congruence with planned learning, authenticity, student consultation, transparency, and diversity. Several researchers have found that classes

DOI: $10.12973 / \mathrm{iji} .2015 .824 \mathrm{a}$ 
using assessment tasks with high degrees of congruence with planned learning, authenticity, student consultation, transparency, and diversity tended to be associated with high levels of student self-efficacy, deep approaches to learning, and increased academic achievement (Alkharusi, 2013; Alkharusi, Aldhafri, Alnabhani, \& Alkalbani, 2013; 2014; Dhindsa, Omar, \& Waldrip, 2007; Dorman, Fisher, \& Waldrip, 2006). However, students' perceptions of the nature of the assessment tasks used in the classroom represent part of the overall student assessment experience that leads up to the perceived classroom assessment environment.

Perceived classroom assessment environment refers to the overall sense or meaning that students make out of the assessment practices by the teacher in the classroom (Brookhart \& DeVoge, 1999). It is a classroom context experienced by students as the teacher determines assessment purposes, develops assessment tasks, defines assessment criteria and standards, provides feedback, and monitors outcomes (Brookhart, 1997). Based on achievement goal theory, Alkharusi (2011) developed a scale to measure students' perceptions of the classroom assessment environment. The scale operationally defined the perceived classroom assessment environment as representing two dimensions: learning- and performance-oriented assessment environments. The learning-oriented assessment environment is characterized by classroom assessment practices that enhance student learning and mastery of subject materials such as asking students to do a variety of meaningful assessment tasks with moderate difficulty, providing them chances to improve their task performance, and giving them informative assessment feedback. The performance-oriented environment is featured by classroom assessment practices like asking students to do difficult and less meaningful assessment tasks with difficult assessment standards and criteria, emphasizing the importance of grades rather than learning, and comparing students' performances to each other. Learning-oriented assessment environment was found to be positively associated with academic selfefficacy and academic achievement whereas performance-oriented assessment environment was found to be negatively associated with academic self-efficacy and academic achievement (Alkharusi, 2009; 2010; 2011). Also, female students tended to perceive their classroom assessment environment as being learning-oriented more than male students whereas male students tended to perceive their classroom assessment environment as being performance-oriented more than female students (Alkharusi, 2011; Meece, Herman, \& McCombs, 2003). As such, measurement and evaluation of students' perceptions of the classroom assessment environment deserve more recognition and investigation.

When considering the items of Alkharusi's (2011) scale, it appears that all of the items assessed the perception of the classroom assessment environment in reference to the "class experience" rather than to the "personal individual experience" (e.g., "In this class, students can find out their strengths"). Yet, Alkharusi (2011) measured perceived classroom assessment environment based on an individual student perception of the assessment environment rather than on a collective class perception of the assessment environment. Brookhart and her colleagues postulated that each classroom has its own "assessment 'character' or environment" perceived by the students and springs from the teacher's assessment practices (Brookhart, 2004, p. 444; Brookhart \& Bronowicz, 
2003). Given that students within the same class are taught by the same teacher, it is critical to reexamine the measurement of the perceived classroom assessment environment at the class level to capture the shared common experience and thus perception of students within the same class about their classroom assessment environment.

\section{Purpose of the study and research questions}

Given the growing interest on students' perceptions of the classroom assessment environment, research is needed to support the assertion that score interpretations from the available instruments such as Alkharusi's (2011) Perceived Classroom Assessment Environment Scale are conceptually accurate representations of the students' perceptions of the classroom assessment environment. Therefore, the purpose of the current study was to evaluate the measurement of the perceived classroom assessment environment by comparing the psychometric properties in terms of construct validity and reliability of Alkharusi's (2011) Perceived Classroom Assessment Environment Scale at the student level and class level. The study was guided by the following research questions:

1. What are the underlying dimensions of Alkharusi's (2011) Perceived Classroom Assessment Environment Scale at the class level versus at the student level?

2. How does Alkharusi's (2011) Perceived Classroom Assessment Environment Scale perform psychometrically at the class level versus at the student level?

\section{METHODS}

Sample

The sample for this study included 4088 students nested within 236 classes randomly selected using a multi-stage sampling process from the second cycle of the basic education grades from all governorates in the Sultanate of Oman. The number of participating students in each class ranged from 9 to 20 with an average of 17 students and a standard deviation of 3.66. Of all participating students, there were 2037 males and 2051 females. Of all participating classes, there were 116 male classes and 120 female classes.

\section{Instrumentation}

The primary instrument in this study was the 18-items Perceived Classroom Assessment Environment Scale developed by Alkharusi (2011) to measure students' perceptions of the classroom assessment environment. As reported in Alkharusi (2011), the items measured students' perceptions of the classroom assessment environment on two dimensions. The first dimension was learning-oriented assessment environment ( 9 items; Cronbach's $\alpha=.82$; e.g., "In this class, students are given a chance to correct their mistakes"). The second dimension was performance-oriented assessment environment ( 9 items; Cronbach's $\alpha=.75$; e.g., "In this class, the teacher compares students' performances to each other"). Responses were obtained on a 5-point Likert scale ranging from 1 (strongly disagree) to 5 (strongly agree). 


\section{Procedures}

A list of all students in the second cycle of the basic education grades from all educational governorates could not be obtained. As such, a multi-stage sampling was carried out to select the students for feasibility reasons. In the first stage, a simple random sample of 106 public schools (63 male schools and 43 female schools) was selected from a list of all schools (221 male schools and 147 female schools) maintained by the Ministry of Education. In the second stage, a random sample of two classes on average of the second cycle of the basic education grades was selected from each of the selected schools. This resulted in a sample of 4088 students situated in 236 classes.

Then, permission was requested from the Ministry of Education and principals of the selected schools to collect data from the students of the selected classes during a regular class period one and a half month prior to the final school examinations. The students were informed that a study is being conducted to examine their perceptions of the classroom assessment environment. They were informed that they were not obligated to participate in the study, and if they wished to participate, their responses would remain confidential. They were also informed that their participation would not influence their grades or relations with the teacher of the subject being assessed. No student rejected the participation in the study. The students were asked to respond to the scale and to write their names to enable the author to match their responses with the grade received in the subject at the end of the semester. The final subject grades were obtained from the school administration.

\section{Statistical analyses}

In relation to the aforementioned purpose of the study and research questions, the following statistical procedures were employed:

1. Student responses to each of the 18-items of the scale were aggregated to the class level. The result was a mean score for each class for each of the 18-items in the scale. Thus, two sets of data were developed based on the same scale items: student-level data and class-level data.

2. The factor structure of the scale items at the student level and at the class level was examined by subjecting student data and class data to principal axis factoring analyses.

3. The reliability was assessed by computing Cronbach's alpha internal consistency reliability estimates for the student data and class data based on the resulting factor structure.

4. Predictive validity was assessed by computing the Pearson product-moment correlation coefficients between the scales' scores and the final grades received in the subject at the end of the semester at the student level and class level.

5. Effect sizes for gender differences on the scales' scores were computed at the student level and class level as evidence for construct validity. The effect sizes were computed based on multivariate analyses of variances. 


\section{RESULTS}

\section{Factor structure}

Two principal axis factoring analyses were separately performed on the student data and class data. At both levels, the initial unrotated solutions resulted in factor structures of two dimensions as suggested by the scree plot and eigenvalues exceeding unity. However, the unrotated factor structures were less meaningful and difficult to interpret due to multiple factor loadings. Therefore, the analyses proceeded to rotate the factor matrices orthogonally with varimax rotation. The analyses yielded two meaningful factors at both levels. The two factors were performance-oriented assessment environment and learning-oriented assessment environment as defined in the original scale developed by Alkharusi (2011).

At the student level, the two factors accounted together $19.68 \%$ of the total variance. The first factor consisted of nine items of the perceived performance-oriented assessment environment accounting for $9.94 \%$ of the variance (eigenvalue $=1.79$ ) with factor loadings $\geq .30$. The second factor consisted of nine items of the perceived learning-oriented assessment environment accounting for $9.74 \%$ of the variance (eigenvalue $=1.75$ ) with factor loadings $\geq .30$.

At the class level, the two factors accounted together $37.85 \%$ of the total variance. The first factor consisted of nine items of the perceived performance-oriented assessment environment accounting for $20.10 \%$ of the variance (eigenvalue $=3.62$ ) with factor loadings $\geq .33$. The second factor consisted of nine items of the perceived learningoriented assessment environment accounting for $17.75 \%$ of the variance (eigenvalue $=$ 3.20) with factor loadings $\geq .40$.

\section{Reliability}

At the student level, internal consistency coefficients for perceived performanceoriented and learning-oriented assessment environment were .67 and .65 as measured by Cronbach's alpha, respectively. Perceived learning-oriented assessment environment correlated negatively with perceived performance-oriented assessment environment, $r(4086)=-.28, p<.001$. At the class level, the internal consistency coefficients for perceived performance-oriented and learning-oriented assessment environment were .83 and .79 as measured by Cronbach's alpha, respectively. Perceived learning-oriented assessment environment correlated negatively with perceived performance-oriented assessment environment, $r(234)=-.40, p<.001$.

\section{Predictive validity}

To evaluate predictive validity of the scale's scores, Pearson product-moment correlation coefficients relating final grades earned in the subject and the subscales' scores were calculated at the student level and class level. At the student level, results indicated that the final grades earned in the subject correlated positively and significantly with the perceived learning-oriented assessment environment, $r(4086)=.10, p<.001$; and negatively and significantly with the perceived performance-oriented assessment environment, $r(4086)=-.28, p<.001$. At the class level, the results revealed that the class final grades earned in the subject correlated positively and significantly with the 
perceived learning-oriented assessment environment, $r(234)=.27, p<.001$; and negatively and significantly with the perceived performance-oriented assessment environment, $r(234)=-.44, p<.001$.

\section{Construct validity}

Based on the classroom environment research showing that female students tend to hold more positive perceptions of their classroom environment compared to male students (e.g., Alkharusi, 2011; Meece et al., 2003), gender differences on the perceived classroom assessment environment scale scores were examined as evidence for construct validity. Multivariate analyses of variances were conducted at the student level and class level. Table 1 presents the means and standard deviations for males and females on the perceived classroom assessment environment subscales at both levels.

At the student level, the results revealed statistically significant multivariate effects of student gender on the perceived classroom assessment environment, $F(2,4085)=$ $116.58, p<.001$, Wilks' Lambda $=.05$. Female students tended on average to perceive their classroom assessment environment as being learning oriented more than male students, $F(1,4086)=71.79, p<.001$, partial $\eta^{2}=.02$. In contrast, male students tended on average to perceive their classroom assessment environment as being performance oriented more than female students, $F(1,4086)=189.83, p<.001$, partial $\eta^{2}=.04$.

At the class level, the results revealed statistically significant multivariate effects of class gender on the perceived classroom assessment environment, $F(2,233)=22.47, p<$ .001 , Wilks' Lambda $=.16$. Female classes tended on average to perceive their classroom assessment environment as being learning oriented more than male classes, $F(1,234)=20.17, p<.001$, partial $\eta^{2}=.08$. In contrast, male classes tended on average to perceive their classroom assessment environment as being performance oriented more than female classes, $F(1,234)=38.48, p<.001$, partial $\eta^{2}=.14$.

Table 1: Means and standard deviations for males and females on the perceived classroom assessment environment subscales at the student level and class level.

\begin{tabular}{|c|c|c|c|c|}
\hline \multicolumn{5}{|l|}{ Student-level } \\
\hline & \multicolumn{2}{|c|}{ Males $(n=2037)$} & \multicolumn{2}{|c|}{ Females $(n=2051)$} \\
\hline & $\mathrm{M}$ & SD & $\mathrm{M}$ & SD \\
\hline Learning-oriented environment & 3.59 & .61 & 3.74 & .58 \\
\hline Performance-oriented environment & 2.92 & .63 & 2.64 & 67 \\
\hline \multicolumn{5}{|l|}{ Class-level } \\
\hline & \multicolumn{2}{|c|}{ Males $(n=116)$} & \multicolumn{2}{|c|}{ Females $(n=120)$} \\
\hline & M & SD & $\mathrm{M}$ & SD \\
\hline Learning-oriented environment & 3.59 & .30 & 3.76 & .27 \\
\hline Performance-oriented environment & 2.90 & .32 & 2.63 & .36 \\
\hline
\end{tabular}

\section{DISCUSSION AND CONCLUSION}

The present study highlighted the importance and value of additional precision in the measurement of perceived classroom assessment environment. The study evaluated the 
psychometric properties of the measurement of the construct at the student level and class level. In summary, the results of the factor analyses yielded two factors, learningoriented and performance-oriented assessment environment, at both levels. However, the two factors explained about $38 \%$ of the variance at the class level compared to about $20 \%$ of the variance at the student level. Coefficients of reliability and validity at the class level were higher than at the student level.

Overall, the findings pointed to a conclusion that perceptions of students about their classroom assessment environment are better tapped by a scale at the collective class level than at the individual student level. The perceived classroom assessment environment subscales at the class level demonstrate reasonable levels of construct validity, predictive validity, and reliability. Hence, these subscales may prove to be useful tools in helping teachers to identify classroom assessment practices targeted at enhancing student learning.

These results supported the assertion that 'classes have an assessment 'character' or environment" that originates from the teacher's classroom assessment practices, and that "students construct their own meaning [of the classroom assessment environment] based in part on their group experiences" (Brookhart, 2004, pp. 444 - 445). In the current study, the classes were independent in the sense that each teacher taught only one class, and as such the results demonstrated that students' perceptions of their classroom assessment environment did vary systematically across classrooms. These findings tended to confirm McMillan and Workman's (1998, p. 29) conclusion that "Assessment and grading continue to be a private activity, with considerable variation among teachers." In addition, the results highlighted the shared common experience and thus perception of students within the same class about their teacher's classroom assessment practices. Therefore, the implication of the findings for future research is that researchers may need to consider not only the individual student perception of the classroom assessment environment which is referred to by Maehr and Midgley (1991, p. $405)$ as the "psychological environment", but also the aggregate perceptions of students in a class about their classroom assessment practices which is referred to as the "objective environment" (Church, Elliot, \& Gable, 2001, p. 44). Specifically, when researchers are interested in the differential performances of classes as a result of teacher assessment practices, the class mean would effectively captures the variability among the classes. A class's collective perception of the assessment environment would be a better predictor of the variation among classrooms in student-level achievement-related outcomes than an individual's student perception. Future research might also need to consider how do the individual student perception about the classroom assessment environment interact with the collective class perception in influencing student achievement-related outcomes. Specifically, there might be a social persuasion effect in the classroom on an individual student perception about the teacher's assessment practices which in turn might affect student achievement-related outcomes. From a socio-cognitive perspective (Coleman, 1990), when a student's perception of the assessment environment are incongruent with the shared perceptions of the class, the student's perceptions might be diminished. Future research in this area is needed to 
further our understanding of both student and collective class perceptions of the classroom assessment environment.

\section{Acknowledgment}

This research was thankfully supported financially by a grant (RC/EDU/PSYC/12/01) from The Research Council in Oman. This funding source had no involvement in the conduct of the research and preparation of the paper.

\section{REFERENCES}

Alkharusi, H. (2009). Classroom assessment environment, self-efficacy, and mastery goal orientation: A causal model. INTI Journal [Special issue on teaching and learning, $104-116$.

Alkharusi, H. (2010). Teachers' assessment practices and students' perceptions of the classroom assessment environment. World Journal on Educational Technology, 2, 2741.

Alkharusi, H. (2011). Development and datametric properties of a scale measuring students' perceptions of the classroom assessment environment. International Journal of Instruction, 4, 105-120.

Alkhrausi, H. (2013). Canonical correlational models of students' perceptions of assessment tasks, motivational orientations and learning strategies. International Journal of Instruction, 6, 21-38.

Alkharusi, H., Aldhafri, S., Alnabhani, H., \& Alkalbani, M. (2013). The impact of students' perceptions of assessment tasks on self-efficacy and perception of task value: A path analysis. Social Behavior and Personality: An international Journal, 41, 16811692.

Alkharusi, H., Aldhafri, S., Alnabhani, H., \& Alkalbani, M. (2014). Modeling the relationship between perceptions of assessment tasks and classroom assessment environment as a function of gender. The Asia-Pacific Education Researcher, 23, 93104.

Brookhart, S. M. (1997). A theoretical framework for the role of classroom assessment in motivating student effort and achievement. Applied Measurement in Education, 10, $161-180$.

Brookhart, S. M. (2004). Classroom assessment: Tensions and intersections in theory and practice. Teachers College Record, 106, 429 - 458.

Brookhart, S. M., \& Bronowicz, D. L. (2003). 'I don't like writing. It makes my fingers hurt': Students talk about their classroom assessment. Assessment in Education: Principles, Policy \& Practice, 10, $221-242$.

Brookhart, S. M., \& DeVoge, J. G. (1999). Testing a theory about the role of classroom assessment in student motivation and achievement. Applied Measurement in Education, $12,409-425$. 
Brookhart, S. M., Walsh, J. M., \& Zientarski, W. A. (2006). The dynamics of motivation and effort for classroom assessment in middle school science and social studies. Applied Measurement in Education, 19, 151-184.

Church, M. A., Elliot, A. J., \& Gable, S. L. (2001). Perceptions of classroom environment, achievement goals, and achievement outcomes. Journal of Educational Psychology, 93, $43-54$.

Coleman, J. S. (1990). Foundations of social theory. Cambridge, Mass: Harvard University Press.

Dhindsa, H. S., Omar, K., \& Waldrip, B. (2007). Upper secondary Bruneian science students' perceptions of assessment. International Journal of Science Education, 29, $1261-1280$.

Dorman, J. P., Fisher, D. L., \& Waldrip, B. G. (2006). Classroom environment, students' perceptions of assessment, academic efficacy and attitude to science: A lisrel analysis. In D. Fisher \& M. S. Khine (Eds.), Contemporary approaches to research on learning environment: Worldviews (pp. 1 -28). Australia: World Scientific Publishing.

Dorman, J. P., \& Knightley, W. M. (2006). Development and validation of an instrument to assess secondary school students' perceptions of assessment tasks. Educational Studies, 32, 47 - 58.

Maehr, M. L., \& Midgley, C. (1991). Enhancing student motivation: A school-wide approach. Educational Psychologist, 26, 399 - 427.

McMillan, J. H., \& Workman, D. J. (1998). Classroom assessment and grading practices: A review of the literature. (ERIC Document Reproduction Service No. ED453263)

Meece, J. L., Herman, P., \& McCombs, B. L. (2003). Relations of learner-centered teaching practices to adolescents' achievement goals. International Journal of Educational Research, 39, 457 - 475.

\section{Turkish Abstract}

\section{Algılanan Sınıf-içi Değerlendirme Ortamının Ölçümünün Bir Değerlendirmesi}

Sınıf-içi değerlendirme ortamı öğretmenler tarafindan belirlenen değerlendirme amacı, görevleri, kriterleri, standartlarının, verilen dönütlerin ve izlenen çıktıların barındığı öğrencilerin deneyimlediği sınıf bağlamı olarak tanımlanabilir (Brookhart, 1997). Bu genellikle sınıftan sınıfa değişen ve öğretmenlerin değerlendirme pratiklerine bağlı bir grup deneyimidir (Brookhart, 2004). Bu yüzden sınıf algı düzeyinin ölçümü araştırmaya değer bir konudur. Bu çalışma algılanan sınıf değerlendirme ortamının ölçümünü öğrenci ve sınıf düzeyine göre karşılaştırarak incelemeyi amaçlamaktadır. Çok aşamalı bir rassal örnekleme süreci kullanarak, Umman'da temel eğitimin ikinci basamağında 236 sınıfta öğrenim gören 4088 öğrenciden veriler toplanmıştır. Öğrenciler 18 maddelik Alkharusi’nin (2011) Algılanan Sınıf Içi Değerlendirme Ölçeği’ne cevap vermişlerdir. Faktör analizi sonuçlarında öğrenme-yönelimli ve performans-yönelimli olarak her iki düzeyde de iki faktör ortaya çıkarmıştır. Fakat, faktörler sınıf düzeyindeki \% 38'lik bir varyansı açılarken, öğrenci düzeyinde \% 20'lik bir varyansı açıklamıştır. Sınıf düzeyinde 
güvenirlik katsayısı .79 ve .83 arasındayken, öğrenci düzeyinde katsayı .65 ile .67 arasındadır.

Anahtar Kelimeler: geçerlik, güvenirlik, değerlendirme, ölçüm, sınıf-içi değerlendirme, öğrenci algis1

\section{French Abstract}

\section{Une Évaluation de la Mesure d'Environnement d'Évaluation de Salle de Classe Perçu}

Un environnement d'évaluation de salle de classe est un contexte de salle de classe expérimenté par des étudiants comme le professeur détermine des buts d'évaluation, développe des tâches d'évaluation, définit des critères d'évaluation et des normes, fournit le retour d'information et contrôle des résultats (Brookhart, 1997). C'est d'habitude une expérience de groupe variant de la classe à la personne à charge de classe sur les pratiques d'évaluation du professeur (Brookhart, 2004). En tant que tel, la mesure de perception de niveau de classe de l'environnement d'évaluation devrait mériter la reconnaissance et l'enquête. Cette étude a visé à évaluer la mesure de l'environnement d'évaluation de salle de classe perçu en comparant les propriétés psychométriques de l'échelle au niveau d'étudiant et le niveau de classe. En utilisant un processus d'échantillonnage aléatoire à plusieurs étages, les données ont été rassemblées de 4088 étudiants a niché dans 236 classes du deuxième cycle de la formation initiale dans le Sultanat de l'Oman. Les étudiants ont répondu l'à 18 articles d'Alkharusi (2011) à l'Échelle d'Environnement d'Évaluation de Salle de classe Perçue. Les résultats de l'axe principal prenant en compte deux facteurs rapportés, environnement d'évaluation axé sur apprentissage et axé sur performance, aux deux niveaux. Cependant, les deux facteurs expliqués environ $38 \%$ du désaccord au niveau de classe comparé à environ $20 \%$ du désaccord au niveau d'étudiant. Les coefficients de fiabilité en termes d'alpha Cronbach se sont étendus entre .79 et .83 au niveau de classe comparé à .65 et .67 au niveau d'étudiant.

Mots Clés: validite, fiabilite, évaluation, mesure, évaluation de salle de classe, perceptions d'étudiant, environnement d'évaluation

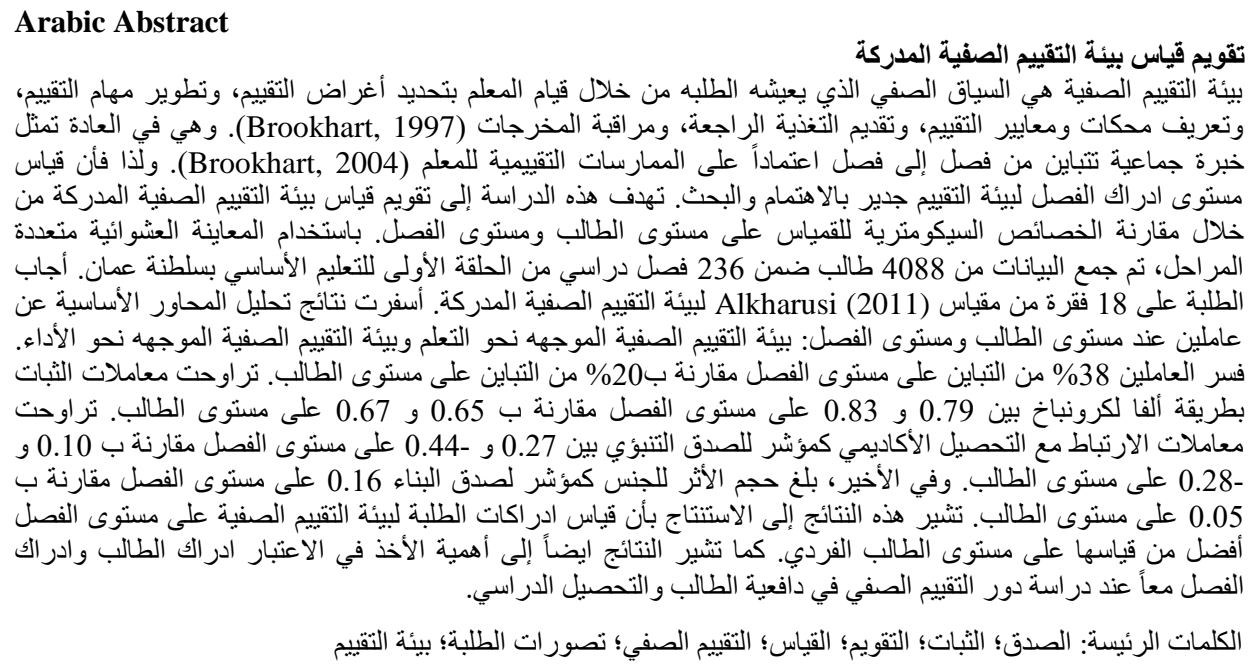

